\title{
Awareness Mahasiswa Akuntansi Pada Konvergensi International Financial Reporting Standards (IFRS) Di Provinsi Bali
}

\author{
Tania Magetsu Putri ${ }^{1}$ \\ Fakultas Ekonomi dan Bisnis \\ Universitas Udayana, Indonesia. \\ Email: tania_magetsu@yahoo.com
}

\author{
Dodik Ariyanto ${ }^{2}$ \\ Fakultas Ekonomi dan Bisnis \\ Universitas Udayana, Indonesia.
}

\begin{abstract}
ABSTRAK
Penelitian ini bertujuan untuk menguji dan memberikan bukti empiris awareness mahasiswa akuntansi yang diukur dengan tingkat interest, knowledge, challenge, dan benefit terkait konvergensi IFRS. Penelitian ini dilakukan pada enam Universitas di Provinsi Bali. serta Perguruan Tinggi Swasta di wilayah koordinasi VIII dan memiliki program Sarjana Akuntansi berstatus aktif. Metode pengumpulan data dilakukan dengan metode survei menggunakan kuesioner. Teknik analisis data yang digunakan adalah Analisis Regresi Linier Berganda. Hasil akhir penelitian menyatakan bahwa variabel tingkat interest, knowledge, dan benefit berpengaruh positif terhadap awareness konvergensi IFRS. Sedangkan variabel tingkat challenge berpengaruh negatif terhadap awareness konvergensi IFRS.
\end{abstract}

Kata Kunci: Tingkat interest, tingkat knowledge, tingkat challenge, tingkat benefit, awareness konvergensi IFRS.

\section{Accounting Student Awareness on International Financial Reporting Standards (IFRS) Convergence in the Province of Bali}

\begin{abstract}
This study aims to provide and empirical awareness of accounting students that is measured by the level of interest, knowledge, challenges, and benefits in influencing IFRS convergence. This research was conducted at six universities in Bali Province and in Higher Education and Private Universities in the VIII Conference area and have an active Bachelor of Accounting program, accounting students. Methods of data collection were conducted by survey method using questionnaire. Data analysis technique used is the Analysis of Multiple Linear Regression. The final result of the study states that the variable level of interest, knowledge, and benefits has a positive effect on awareness of IFRS convergence. While the level of challenge variable has a negative effect towards IFRS convergence awareness.
\end{abstract}

Keywords: Interest level, knowledge level, challenge level, benefit level, awareness of IFRS convergence.

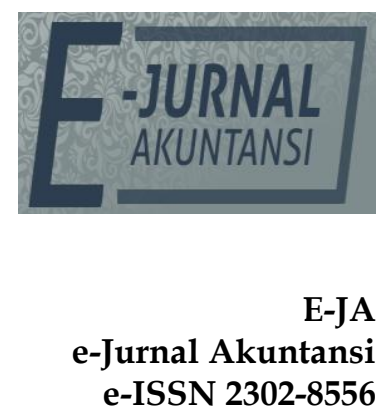

Denpasar,

Vol. 28 No. 3

September 2019

Hal. 1633-1649

Artikel masuk:

11 November 2018

Tanggal diterima:

11 September 2019 


\section{PENDAHULUAN}

Akuntansi adalah sebuah aktivitas jasa yang bertujuan memberikan informasi yang dapat digunakan dalam pengambilan keputusan ekonomi. Dalam melakukan aktivitas tersebut terdapat standar yang mengaturnya yaitu disebut standar akuntansi. Standar akuntansi merupakan sebuah pedoman yang dibuat untuk memberikan suatu gambaran umum dalam membuat laporan keuangan. Salah satu standar akuntansi yang banyak digunakan saat ini adalah International Financial Reporting Standards (IFRS) (Fong, 2016).

IFRS merupakan seperangkat standar dan kerangka yang diadopsi oleh badan penyusun standar akuntansi internasional bernama International Accounting Standards Board (IASB). IFRS sebelumnya dikenal dengan nama International Accounting Standards (IAS) yang diterbitkan oleh International Accounting Standards Committee (IASC). Berbagai penelitian sudah dilakukan dalam menilai dampak penerapan IFRS disetiap sektor industry diberbagai negara (Heykal et al., 2014), (Poudel \& Hellmann, 2014), (Nurunnabi, 2014)).

Ilmu akuntansi senantiasa berkembang sesuai dengan kebutuhan bisnis dan peraturan yang berlaku di dalam entitas bisnis. Standar Akuntansi Keuangan berbasis International Financial Standard Report (IFRS) merupakan salah satu kesepakatan pemerintah Indonesia sebagai anggota G20 forum telah diberlakukan secara efektif di Indonesia per 1 Januari 2012 dan diharapkan dapat sudah diimplementasikan pada tahun 2019. Konvergensi IFRS ini diberlakukan wajib bagi perusahaan yang telah go public. Standar akuntansi di Indonesia yang berlaku saat ini mengacu pada US GAAP (United Stated Generally Accepted Accounting Standard), namun pada beberapa pasal sudah mengadopsi IFRS yang sifatnya harmonisasi. Adopsi yang dilakukan Indonesia saat ini sifatnya belum menyeluruh, baru sebagian (harmonisasi).

Setiap negara memiliki standar akuntansi yang berbeda-beda dalam perlakuan, metode, penyajian dan pelaporannya. Adanya perbedaan tersebut akan menyulitkan para pengguna laporan keuangan yang lingkup usahanya melewati batas negara. Penyebab perbedaan standar akuntansi disebabkan oleh lingkungan ekonomi, lingkungan politik, dan teori akuntansi yang ada dalam negara tersebut. Agar pemahaman laporan keuangan menjadi lebih mudah, maka perlu adanya aturan atau standar akuntansi yang seragam. Atas dasar hal tersebut, maka muncullah isu konvergensi Standar Akuntansi Keuangan (PSAK) ke International Financial Reporting Standards (IFRS). Dengan adanya konvergensi tersebut diharapkan menjadi jembatan pemahaman laporan keuangan yang seragam sehingga tidak ada lagi kesalahan persepsi dalam menginterpretasikan laporan keuangan (Susanti, 2018).

Salah satu tujuan konvergensi IFRS adalah untuk membantu perusahaan mengkomunikasikan laporan keuangannya, dan digunakan stakeholder untuk membandingkan informasi keuangan perusahaan di seluruh dunia (Helen dan Raymond, 2013). IASB bertujuan agar semua negara mengadopsi IFRS secara penuh, agar informasi keuangan lebih berkualitas, transparan dan lebih mudah diperbandingkan. Tujuan IASB hampir tercapai, namun memang tidak ada batas waktu yang pasti kapan semua negara mengadopsi IFRS. Ketika tujuan IASB tercapai, maka pelaporan keuangan di tingkat global akan menggunakan standar ini (Farahmita, 2012). Perusahaan yang bersaing di pasar dunia mau tidak mau 
harus menganut pelaporan keuangan sesuai standar internasional agar terciptanya keseragaman informasi dari berbagai negara serta mudah dalam pengambilan keputusan ekonomi (Flynn, 2008). Apalagi ditambah sekarang Indonesia ikut serta dalam perdagangan bebas ASEAN di tahun 2015 sebagai bagian dari ASEAN Community, ini memberikan tantangan tersendiri bagi akuntan untuk dapat berkompetisi dengan akuntan dari Negara lainnya. Wakil Menteri Keuangan, Mahendra Siregar dalam Ikatan Akuntan Indonesia (2013) menyatakan bahwa daya saing akuntan di Indonesia masih rendah dibandingkan dengan akuntan-akuntan negara lain, disebabkan oleh rendahnya kesadaran akuntan Indonesia memperbaharui ilmu-ilmu akuntansi, salah satunya adalah konvergensi IFRS dalam standar akuntansi keuangan di Indonesia. Penelitian yang dilakukan oleh Wahyuni (2012) juga menemukan bahwa akuntan publik yang tidak berafiliasi dengan pihak asing, tidak siap dengan konvergensi IFRS, meskipun secara umum akuntan Indonesia yakin Indonesia siap dengan perubahan ini.

Zeghal dan Mhedhbi (2006) telah melakukan riset mengenai analisis faktor-faktor yang mempengaruhi adopsi standar akuntansi internasional di negara berkembang. Mereka menemukan bahwa adopsi IFRS di negara berkembang dipengaruhi oleh salah satu faktor yaitu tingkat pendidikan yang tinggi. Penelitian Sundem (dalam Nuraini, 2007) mengkhawatirkan akan ketidakjelasan pada industri akuntansi yang dihasilkan oleh pendidikan tinggi akuntansi, hal ini dikarenakan banyak perguruan tinggi tidak mampu membuat anak didiknya menguasai dengan baik pengetahuan dan keterampilan hidup.

Kemunculan IFRS serta konvergensinya juga telah mengundang berbagai pendapat ataupun persepsi dari semua pihak pemakai laporan keuangan termasuk didalamnya adalah para akuntan pendidik, mahasiswa dan praktisi (auditor dan akuntan). Berdasarkan permasalahan-permasalahan tersebut, menuntut terjadinya perubahan dalam bidang pendidikan akuntansi. Untuk itu, perguruan tinggi yang ada di Indonesia diharapkan untuk dapat mengganti kurikulum yang lebih berbasis IFRS. Peran Peguruan tinggi sangat dibutuhkan bagi mahasiswa terutama mahasiswa akuntansi yang nantinya akan menjadi output yang berguna seperti auditor, pekerja akuntan. Mahasiswa akuntansi yang merupakan calon pekerja akuntan serta auditor, juga harus lebih aware atau peduli tentang isu konvergensi IFRS ini. Awareness dalam hal ini dapat diukur dengan tingkat interest, knowledge, challenge, dan benefit. Penelitian (Barth et al., 2008) juga menyatakan bahwa perkembangan pelaporan keuangan global berimplikasi perlunya mengedukasi mahasiswa mengenai laporan keuangan global.

Menjadi suatu pertimbangan bagi pihak perguruan tinggi untuk merencanakan integrasi IFRS ke dalam kurikulum akuntansi. Integrasi ini tentunya harus memerhatikan cara untuk mengembangkan minat mahasiswa dalam memperbaharui ilmunya. Minat yang dimiliki oleh mahasiswa juga berpengaruh terhadap adopsi IFRS ini. Dimana minat merupakan keinginan dari seseorang/mahasiswa dalam mendalami ilmunya untuk menjadi tenaga akuntan yang profesional. Minat belajar sangat berpengaruh pada setiap tindakan dalam proses belajar (Nuraini, 2007). Penelitian (Christiani, 2015) menunjukkan bahwa 
minat belajar mahasiswa yang tinggi maka mahasiswa tersebut akan semakin paham dalam memahami IFRS.

Tingkat pengetahuan (knowledge) mengenai IFRS merupakan segala sesuatu yang diketahui berkenaan dengan IFRS agar dapat menjadikan mahasiswa lebih memahami informasi keuangan, dan implikasi dari setiap perubahan dalam standar. IFRS saat ini menjadi kompetensi wajib bagi akuntan, auditor, regulator, dan akuntan pendidik dengan kesiapan mengadopsi IFRS sebagai standar akuntansi tunggal. Mahasiswa akuntansi wajib memiliki pengetahuan tentang implikasi dan penerapan standar yang terbaru agar setelah lulus nanti dapat menjadi sumber daya yang kompeten dalam persaingan global. Penelitian yang dilakukan oleh (Zeghal \& Mhedhbi, 2006) menyatakan bahwa tingkat edukasi berpengaruh signifikan positif terhadap proses adopsi IFRS.

Integrasi kurikulum ke IFRS yang dilakukan oleh Universitas tentunya menemukan tantangan (challenge) yang dihadapi baik itu dari tingkat kesiapan para dosen, para intruktur, serta mahasiswa yang akan menerima materi IFRS tersebut. Dalam penelitian (Gayatri et al., 2016) kesiapan sumber daya manusia yaitu pendidik merupakan narasumber dalam menghadapi perkembangan ilmu pengetahuan yaitu IFRS. Kesiapan ini akan sangat menentukan proses transfer ilmu pengetahuan. Tantangan (challenge) dalam adopsi IFRS merupakan sesuatu yang menggugah tekad untuk dapat meningkatkan kemampuan mengatasi masalah yang dihadapi dalam proses konvergensi ini. Kendala selanjutnya yang paling besar dalam adopsi IFRS yaitu kendala bahasa. Dalam memahami suatu makna dari bahasa sangat sulit untuk dilakukan dan tidak jarang dapat menimbulkan perbedaan persepi dari setiap negara yang mengadopsinya. Penelitian sebelumnya yang dilakukan oleh (Phan et al., 2018) bahwa tantangan yang dirasakan dalam kemauan dalam mengadopsi adalah berpengaruh negatif.

Pengembangan pembelajaran berbasis IFRS diharapkan mampu meningkatkan kepercayaan mahasiswa bahwa mempelajari IFRS dapat membantu dan sangat berguna bagi mereka sebagai akuntan di masa depan. Sesuai dengan penelitian Warsono (2010), tingkat manfaat (benefit) yang memperhatikan IFRS bertujuan agar mahasiswa memiliki pengetahuan memadai di bidang akuntansi yang berlaku di dunia praktik akuntansi. Penelitian yang dilakukan sebelumnya oleh (Phan et al., 2018) tingkat manfaat berpengaruh positif terhadap konvergensi IFRS.

Terkait dengan topik ini, beberapa penelitian sebelumnya yang meneliti mengenai awareness konvergensi IFRS. (Phan et al., 2018) menyatakan bahwa tingkat challenge berpengaruh negatif terhadap awareness konvergensi IFRS dan tingkat benefit berpengaruh posotof terhadap awareness konvergensi IFRS. (Brochet et al., 2011) dan (Soderstrom \& Sun, 2008) menyatakan bahwa manfaat yang berpengaruh positif terhadap kemauan untuk mengadopsi IFRS. dari (Zeghal \& Mhedhbi, 2006) menyatakan bahwa tingkat edukasi berpengaruh signifikan positif terhadap proses adopsi IFRS.

Berdasarkan uraian diatas, penelitian ini menambahkan variabel knowledge dan interest untuk dianalisa pengaruhnya terhadap awareness mahasiswa akuntansi pada konvergensi IFRS di Univeritas Provinsi Bali. Tingkat interest dan knowledge sangat penting perannya dalam konvergensi IFRS dimana mahasiswa bisa lebih aware terhadap konvergensi IFRS apabila mahasiswa 
akuntansi memiliki minat serta pengetahuan yang tinggi terhadap perkembangan konvergensi IFRS.

Rumusan masalah dari penelitian ini adalah apakah tingkat interest, knowledge, challenge, dan benefit berpengaruh terhadap awareness mahasiswa akuntansi pada kovergensi IFRS di Provinsi Bali?. Tujuan penelitian ini adalah untuk mengetahui pengaruh tingkat interest, knowledge, challenge, dan benefit terhadap awareness mahasiswa akuntansi pada konvergensi IFRS. Penelitian ini diharapkan dapat memberikan manfaat, baik manfaat teoritis dan manfaat praktis. Secara teoritis, penelitian ini memperkuat awareness mahasiswa akuntansi dengan menggunakan Teori Taksonomi Bloom dan Theory of Reasoned Action (TRA), serta dapat memberikan gambaran dan memperluas pengetahuan dilingkungan akademis. Memberikan manfaat bagi pihak-pihak yang berkepentingan khususnya mengenai tingkat awareness terhadap IFRS. Secara praktis, penelitian ini dapat menjadi suatu masukan atau pertimbangan bagi pihak pengajar mahasiswa dalam bidang akuntansi dalam mengaplikasikan materi IFRS guna meningkatkan kemampuan dalam awareness terhadap IFRS, serta dapat memberikan tambahan pengetahuan tentang tingkat awareness terhadap perkembangan IFRS.

Taksonomi berasal dari dua kata dalam bahasa Yunani yaitu tassein yang berarti mengklasifikasi dan nomos yang berarti aturan. Jadi taksonomi berarti hierarki klasifikasi atas prinsip dasar atau aturan. Istilah ini kemudian digunakan oleh Benjamin Samuel Bloom, seorang psikolog bidang pendidikan yang melakukan penelitian dan pengembangan mengenai kemampuan berpikir dalam proses pembelajaran. Taksonomi Bloom adalah struktur hierarki (bertingkat) yang mengidentifikasikan keterampilan berpikir mulai dari jenjang yang rendah hingga yang tinggi. Benjamin. S. Bloom membuat suatu klasifikasi berdasarkan urutan keterampilan berpikir dalam suatu proses yang semakin lama semakin tinggi tingkatannya. Pada tahun 1966 Simpson menambahkan ranah psikomotor melengkapi apa yang telah dibuat oleh bloom. Dengan demikian menjadi tiga ranah yaitu ranah kognitif, ranah afektif dan ranah psikomotor (Ramlan Effendi, 2015).

Ranah pertama dari teori Bloom sangat berhubungan dengan awareness mahasiswa, dimana apabila mahasiswa memiliki pengetahuan yang tinggi mengenai IFRS maka tingkatan yang lebih tinggi akan tercapai dan secara otomatis akan aware terhadap pembelajaran IFRS. Ranah kedua dari teori Bloom yaitu ranah afektif yang salah satunya terdapat tingkatan penerimaan. Penerimaan dalam hal ini dapat dicontohkan dengan sikap seseorang ketika mendengarkan penjelasan pendidik dimana mereka mau menerima nilai-nilai yang diajarkan pada mereka dan mereka memiliki kemauan untuk menggabungkan diri dengan nilai tersebut. Ranah ketiga yaitu ranah psikomotrik. Ranah ini meliputi kompetensi melakukan pekerjaan dengan melibatkan anggota badan serta kompetensi yang berkaitan dengan gerak fisik (psikomotorik). Ranah ini meliputi beberapa kategori yaitu meniru, memanipulasi, pengalamiahan, dan artikulasi. Dalam ranah ketiga Bloom jika dikaitkan dengan awareness pada konvergensi IFRS apabila seseorang dalam mempelajari standar akuntansi tidak bisa hanya memahami dan menghapalkan standar tersebut melainkan kita harus melatih bagian pskomotrik kita agar kita terbiasa menggunakan standar akuntansi yang berlaku global tersebut sehingga apabila terdapat tantangan-tantangan dapat diatasi dengan mudah dan dengan begitu manfaat yang didapat sangat berguna setelah lulus nanti. 
Theory of Reasoned Action (TRA) pertama kali diperkenalkan oleh Martin Fishbein dan Ajzen dalam Jogiyanto (2007) yang menghubungkan antara keyakinan (belief), sikap (attitude), niat (intention) dan perilaku (behavior). Konsep penting dalam teori ini adalah fokus perhatian (salience), yaitu mempertimbangkan sesuatu yang dianggap penting. Jogiyanto (2007) berpendapat bahwa niat merupakan fungsi dari dua determinan dasar, yaitu sikap individu terhadap perilaku (merupakan aspek personal) dan persepsi individu terhadap tekanan sosial untuk melakukan atau untuk tidak melakukan perilaku yang disebut dengan norma subyektif. Secara singkat, praktik atau perilaku menurut Theory of Reasoned Action (TRA) dipengaruhi oleh niat, sedangkan niat dipengaruhi oleh sikap dan norma subyektif. Secara lebih sederhana, teori ini mengatakan bahwa seseorang akan melakukan suatu perbuatan apabila ia memandang perbuatan itu positif dan bila ia percaya bahwa orang lain ingin agar ia melakukannya. Apabila seseorang percaya bahwa mempelajari IFRS memiliki banyak manfaat maka seseorang tersebut akan mengubah sikapnya sesuai dengan tujuan yang dicapai dan secara langsung akan mempengaruh minatnya dalam mempelajari IFRS karena ia memandang bahwa sesuatu yang dilakukannya akan berdampak positif dan juga akan mengubah perilakunya untuk lebih memperdulikan perkembangan dari hal-hal yang dipelajarinya.

Menurut Nilson (2008), integrasi IFRS akan berdampak pada masa depan informasi akuntansi. Persiapan memasukkan IFRS dan IAS (International Accounting Standards) ke dalam kurikulum akuntansi sudah dipersiapkan, namun beberapa masalah perlu ditangani. Masalah utama adalah kurangnya materi kursus yang sesuai dan yang kedua adalah buku teks usang yang perlu diperbarui untuk adopsi IFRS. Cara yang tepat untuk transisi semua perusahaan A.S. ke IFRS memerlukan pelatihan yang berkaitan dengan IFRS untuk investor, manajemen, auditor, dan penyertaan IFRS dalam kurikulum Akuntansi (Moqbel \& Bakay, 2010).

Slameto (2010) minat merupakan ketertarikan seseorang dalam melakukan sesuatu. Hal-hal yang berhubungan dengan perilaku belajar yang baik dapat dilihat dari kebiasaan mengikuti pelajaran, kebiasaan membaca buku, kunjungan ke perpustakaan dan kebiasaan menghadapi ujian (Marita et al., 2008). Oleh karena itu, dengan perilaku belajar atau minat belajar yang baik akan mengarah pada pemahaman terhadap pelajaran yang maksimal. Sebaliknya, dampak dari perilaku belajar atau minat belajar yang kurang baik akan mengarah pada pemahaman terhadap pelajaran kurang maksimal. Penelitian sebelumnya ditemukan oleh (Widaningrum et al., 2010) bahwa minat belajar mahasiswa berpengaruh positif terhadap pemahaman IFRS. Maka dari itu hipotesis dari variabel ini adalah

$\mathrm{H}_{1}$ : Tingkat Interest berpengaruh positif terhadap awareness mahasiswa akuntansi pada konvergensi IFRS

Tingkat pengetahuan dalam konvergensi IFRS ini dapat diukur dengan informasi yang didapat yang berhubungan dengan IFRS, pemahaman akan adanya perubahan standar yang diterapkan. Penelitian sebelumnya yang dilakukan oleh (Helen dan Raymond, 2013) hanya sebagian siswa yang menyadari bahwa Dewan Standar Akuntansi di Hongkong mengadopsi IFRS. 
Penelitian sebelumnya dari (Zeghal \& Mhedhbi, 2006) menyatakan bahwa tingkat edukasi berpengaruh signifikan positif terhadap proses adopsi IFRS. Semakin seseorang memiliki pengetahuan yang tinggi terhadap IFRS, maka kepedulian terhadap konvergensi IFRS akan tinggi pula. Maka dari itu hipotesisnya adalah

$\mathrm{H}_{2}$ : Tingkat Knowledge berpengaruh positif terhadap awareness mahasiswa akuntansi pada konvergensi IFRS

Dalam mengkonvergensi IFRS diperlukan judgement dan pedoman dalam intrepertasinya. Berbagai riset menunjukkan bahwa professional judgment itu sendiri problematis karena terkendala oleh faktor-faktor institusional di sebuah negara (antara lain: budaya, regulasi profesi akuntan, sistem hukum dan penegakannya, sistem keuangan, dan sistem pajak) (Wehrfritz dan Haller 2014; Mala dan Chand, 2014; Perera et al., 2012; Nobes, 2013; Eichler, 2012 dan Jermakowicz et al., 2014). Selain itu tantangan dalam bahasa juga sangat dirasakan dalam implementasi IFRS. Semakin banyak tantangan yang dihadapi oleh seseorang dalam mempelajari IFRS maka akan semakin malas atau enggan mahasiswa tersebut dalam mempelajari IFRS. Begitu pula bagi negara yang ingin mengadopsi IFRS apabila dalam rencana tersebut banyak terdapat tantangan yang dihadapi maka negara tersebut lebih memilih untuk tetap mempertahankan Standar domestik yang diterapkan pada negara masingmasing dan implementasinya banyak mahasiswa masih mempelajari standar yang belum dikonvergensi ke IFRS karena negara masih enggan untuk mensosialisasikan mengenai konvergensi IFRS. Dalam penelitian (Phan et al., 2018) juga menyimpulkan bahwa tantangan yang dirasakan dalam kemauan dalam mengadopsi IFRS di Vietnam adalah berpengaruh negatif. (Sharma et al., 2017) juga merekomendasikan agar IASB sekarang harus fokus pada implementasi IFRS, selain memperbarui / membuat IFRS dengan pandangan untuk meminimalkan kesulitan yang dihadapi oleh negara yang akan implementasi. Maka dari itu hipotesisnya adalah

$\mathrm{H}_{3}$ : Tingkat Challenge berpengaruh negatif tehadap awareness mahasiswa akuntansi pada konvergensi IFRS.

Mempelajari IFRS sangat banyak memiliki manfaat yang pastinya akan membantu calon profesi akuntan dalam mengembangkan skill mereka dalam melakukan transaksi bisnis. Penelitian yang dilakukan oleh (Phan et al., 2018), (Brochet et al., 2011), dan (Soderstrom \& Sun, 2008) menemukan bahwa manfaat yang dirasakan seperti, komparabilitas dan reliabilitas yang terkait dengan IFRS berpengaruh positif terhadap kemauan untuk mengadopsi IFRS di Vietnam. Maka hipotesisnya adalah

$\mathrm{H}_{4}$ : Tingkat Benefit berpengaruh positif terhadap awareness mahasiswa akuntansi pada konvergensi IFRS

\section{METODE PENELITIAN}

Populasi dalam penelitian ini adalah mahasiswa S1 Jurusan Akuntansi yang berkuliah di Perguruan Tinggi Provinsi Bali. Teknik penentuan sampel yang digunakan adalah dengan teknik purposive sampling. Kriteria pengambilan sampel dalam penelitian ini adalah: a) Responden Mahasiswa aktif yang berkuliah di Perguruan Tinggi Negeri maupun Swasta Provinsi Bali. b) 
Responden yang berkuliah di Perguruan Tinggi Swasta masuk dalam lingkup wilayah koordinasi VIII. c) Responden berkuliah di Perguruan Tinggi dengan jenis Universitas dan status dari Universitas tersebut adalah aktif, serta memiliki program Sarjana Akuntansi berstatus aktif. d) Responden harus berasal dari jurusan Akuntansi. e) Responden berada pada semester V dan VII. f) Responden telah mengambil dan sedang menempuh mata kuliah Akuntansi keuangan Lanjutan, Teori Pasar Modal, dan Teori Akuntansi.

Tabel 1. Daftar Nama Universitas Aktif di Provinsi Bali

\begin{tabular}{ccccc}
\hline No & Nama Universitas & $\begin{array}{c}\text { Keberadaan } \\
\text { Jurusan } \\
\text { Akuntansi }\end{array}$ & $\begin{array}{c}\text { Aktif/Tidak } \\
\text { Aktif }\end{array}$ & Sampel \\
\hline 1 & Universitas Udayana & Ada & Aktif & 109 \\
2 & Universitas Pendidikan Ganesha & Ada & Aktif & 47 \\
3 & Universitas Mahendradatta & Tidak Ada & - & - \\
4 & Universitas Ngurah Rai & Tidak Ada & - & - \\
5 & Universitas Mahasaraswati Denpasar & Ada & Aktif & 35 \\
6 & Universitas Pendidikan Nasional & Ada & Aktif & 27 \\
7 & Universitas Dwijendra & Tidak Ada & - & - \\
8 & Universitas Tabanan & Tidak Ada & - & - \\
9 & Universitas Warmadewa & Ada & Aktif & 40 \\
10 & Universitas Panji Sakti Singaraja & Ada & Tidak Aktif & - \\
11 & Universitas Hindu Indonesia & Ada & Aktif & 24 \\
12 & Universitas Teknologi Indonesia & Tidak Ada & - & - \\
13 & Universitas Bali Dwipa & Ada & Aktif & - \\
\hline
\end{tabular}

Sumber: Ristekdikti, 2018

Variabel bebas (independent) dalam penelitian ini adalah tingkat interest (X1), knowledge (X2), challenge (X3), dan benefit (X4). Variabel terikat (dependent) dalam penelitian ini adalah tingkat awareness $(\mathrm{Y})$ terhadap IFRS.

Metode pengumpulan data dilakukan dengan metode survey dengan pendekatan kuantitatif. Pengumpulan data dilakukan melalui kuesioner, survei dilakukan dengan cara menyebarkan kuesioner secara langsung ke responden dengan menggunakan google form yang menjadi sampel penelitian. Kuisioner dalam penelitian ini menggunakan skala likert 1 sampai dengan 5 dan dummy (01).

Tabel 2. Daftar Variabel, Indikator, dan Skala Pengukuran

\begin{tabular}{lll}
\hline \multicolumn{1}{c}{ Variabel } & \multicolumn{1}{c}{ Indikator } & Skala Pengukuran \\
\hline Awareness & (a) Kepedulian terhadap adopsinya & Skala Dummy 0 dan 1 \\
IF & IFRS di Indonesia & \\
& (b) Kepedulian terhadap kunci \\
perbedaan antara PSAK dengan & \\
IFRS & \\
Interest & (a) Pendapat mengenai IFRS \\
(X1) & (b) Pendapat mengenai pelajaran IFRS \\
& (c) Kemampuan dalam mengetahui \\
& IFRS \\
& (d) Materi mengenai IFRS \\
\hline
\end{tabular}

Bersambung ... 


\begin{tabular}{|c|c|c|}
\hline & $\begin{array}{l}\text { (e) Pendapat mengenai keberhasilan } \\
\text { dalam pembelajaran IFRS } \\
\text { (f) Perbandingan PSAK dengan IFRS } \\
\text { (g) Keingintahuan terhadap materi } \\
\text { IFRS } \\
\text { (h) Kemampuan dalam meraih tujuan } \\
\text { dalam mempelajari IFRS }\end{array}$ & Skala Likert 1 sampai 5 \\
\hline \multirow{2}{*}{$\begin{array}{l}\text { Knowledge } \\
(\mathrm{X} 2)\end{array}$} & (a) Kompetensi terhadap IFRS & Skala Likert 1 sampai 5 \\
\hline & $\begin{array}{l}\text { (b) Kebutuhan terhadap IFRS } \\
\text { (c) Frekuensi penggunaan IFRS }\end{array}$ & \\
\hline \multirow[t]{4}{*}{$\begin{array}{l}\text { Challenge } \\
(\mathrm{X} 3)\end{array}$} & $\begin{array}{l}\text { (a) Tidak diterjemahkan tepat waktu } \\
\text { (b) Bimbingan yang tidak memadai } \\
\text { (c) Mengedukasi mahasiswa keuangan } \\
\text { (d)Cakupan terbatas dalam kurikulum } \\
\text { akuntansi }\end{array}$ & Skala Likert 1 sampai 5 \\
\hline & $\begin{array}{l}\text { (e) Lemahnya badan akuntansi } \\
\text { profesional }\end{array}$ & \\
\hline & $\begin{array}{l}\text { (f) Kurangnya skill dan tidak } \\
\text { memadainya pengetahuan dari } \\
\text { profesional akuntan Indonesia }\end{array}$ & \\
\hline & $\begin{array}{l}\text { (g) Perlunya lingkungan etis yang } \\
\text { sehat }\end{array}$ & \\
\hline \multirow[t]{8}{*}{ Benefit (X4) } & (a) Pandangan mengenai & Skala Likert 1 sampai 5 \\
\hline & $\begin{array}{l}\text { perbandingan kinerja keuangan } \\
\text { global }\end{array}$ & \\
\hline & $\begin{array}{l}\text { (b) Pandangan mengenai kemampuan } \\
\text { dalam menyampaikan informasi } \\
\text { keuangan secara global }\end{array}$ & \\
\hline & (c) Pandangan terhadap IASB & \\
\hline & (d) Pandangan terhadap biaya & \\
\hline & Kepaturan standar akuntanst & \\
\hline & $\begin{array}{l}\text { (e) Kelayakan } \\
\text { mengembangkan IFRS }\end{array}$ & \\
\hline & $\begin{array}{l}\text { (f) Pandangan terhadap adopsi IFRS } \\
\text { yang dapat mengurangi aktivitas } \\
\text { illegal. }\end{array}$ & \\
\hline
\end{tabular}

Sumber: Data Penelitian, 2018

Penelitian ini menggunakan skor jawaban kuesioner dari responden sebagai data kuantitatif, dengan menggunakan sumber data primer. Data primer dalam penelitian ini adalah jawaban mahasiswa terhadap tingkat awareness dari serangkaian pernyataan kuesioner yang diajukan dalam penelitian.

Teknik analisis dalam penelitian ini adalah regresi linear berganda. Model regresi linear berganda dirumuskan sebagai berikut.

$$
Y=\alpha+\beta_{1} X_{1}+\beta_{2} X_{2}+\beta_{3} X_{3}+\beta_{4} X_{4}+\varepsilon
$$

Keterangan:

$\mathrm{Y}=$ Tingkat Awareness

$\mathrm{a}=$ Konstanta

$\beta_{\mathrm{i}}=$ Koefisien Regresi 
$\mathrm{X}_{1}=$ Tingkat Interest

$\mathrm{X}_{2}=$ Tingkat Knowledge

$\mathrm{X}_{3}=$ Tingkat Challenge

$\mathrm{X}_{4}=$ Tingkat Benefit

$\boldsymbol{\varepsilon}=$ standar error

Data yang dikumpulkan dalam penelitian ini berupa data ordinal sehingga data yang dikumpulkan yang bersumber dari kuisioner ini harus diubah dalam bentuk interval menggunakan method of successive interval (MSI).

\section{HASIL DAN PEMBAHASAN}

Statistik deskriptif disajikan untuk memberikan informasi mengenai karakteristik variabel-variabel penelitian yang terdiri dari jumlah amatan, nilai minimum, nilai rata-rata, dan standar deviasi (simpangan baku) dengan $\mathrm{N}$ merupakan banyaknya responden penelitian. Hasil analisis statistik deskriptif dapat dilihat pada Tabel 3.

Tabel 3. Hasil Statistik Deskriptif

\begin{tabular}{lccccc}
\hline \multicolumn{1}{c}{ Variabel } & N & Min. & Maks. & $\begin{array}{c}\text { Rata- } \\
\text { rata }\end{array}$ & $\begin{array}{c}\text { Simpangan } \\
\text { Baku }\end{array}$ \\
\hline Tingkat Interest $\left(\mathrm{X}_{1}\right)$ & 282 & 1,21 & 5,52 & 3,5112 & 0,58679 \\
Tingkat Knowledge $\left(\mathrm{X}_{2}\right)$ & 282 & 1,00 & 5,47 & 3,8075 & 0,78702 \\
Tingkat Challenge $\left(\mathrm{X}_{3}\right)$ & 282 & 1,65 & 4,95 & 3,5684 & 0,66521 \\
Tingkat Benefit $\left(\mathrm{X}_{4}\right)$ & 282 & 1,00 & 4,57 & 3,1027 & 0,69188 \\
Tingkat Awareness $(\mathrm{Y})$ & 282 & 0,00 & 1,30 & 0,7756 & 0,51294 \\
\hline
\end{tabular}

Sumber: Data Penelitian, 2018

Pada table 3, variabel tingkat interest $\left(\mathrm{X}_{1}\right)$ memiliki nilai rata-rata sebesar 3,5112 dengan nilai minimum 1,21 dan nilai maksimum 5,52. Hal ini menunjukkan bahwa mahasiswa akuntansi di Universitas Provinsi Bali memiliki ketertarikan cukup terhadap mempelajari IFRS karena dapat dilihat nilai ratarata lebih mendekati nilai maksimal, yang artinya sebagian besar responden cenderung menjawab ragu-ragu pada ke-tujuh item pernyataan dalam variabel tingkat interest. Nilai standar deviasi yang dimiliki oleh tingkat interest adalah 0,58679 dimana lebih kecil dari nilai rata-ratanya yaitu 3,5112, sehingga mengindikasikan bahwa hasil yang cukup baik. Hal tersebut dikarenakan standar deviasi adalah pencerminan penyimpangan yang sangat tinggi, sehingga penyebaran data menunjukkan hasil yang normal dan tidak menyebabkan bias.

Variabel tingkat knowledge $\left(\mathrm{X}_{2}\right)$ memiliki nilai rata-rata sebesar 3,8075 dengan nilai minimum 1,00 dan nilai maksimum 5,47. Hal ini menunjukkan pengetahuan yang dimiliki oleh mahasiswa akuntansi di Universitas Provinsi Bali sudah baik. Hal tersebut juga dapat dilihat dari nilai rata-rata lebih mendekati nilai maksimal, yang artinya sebagian besar responden cenderung menjawab setuju pada ke-tiga item pernyataan dalam variabel tingkat knowledge. Nilai standar deviasi yang dimiliki oleh tingkat knowledge adalah 0,78702 dimana lebih kecil dari nilai rata-ratanya yaitu 3,8075, sehingga mengindikasikan bahwa hasil yang cukup baik. Hal tersebut dikarenakan standar deviasi adalah pencerminan penyimpangan yang sangat tinggi, sehingga penyebaran data menunjukkan hasil yang normal dan tidak menyebabkan bias. 
Variabel tingkat challenge $\left(X_{3}\right)$ memiliki nilai rata-rata sebesar 3,5684 dengan nilai minimum 1,65 dan nilai maksimum 4,95. Hal ini menunjukkan tingkat challenge yang dihadapi oleh mahasiswa akuntansi di Universitas Provinsi Bali cenderung rendah. Hal tersebut juga dapat dilihat dari nilai ratarata lebih mendekati nilai maksimal, yang artinya sebagian besar responden cenderung menjawab setuju pada ke-tujuh item pernyataan dalam variabel tingkat challenge. Nilai standar deviasi yang dimiliki oleh tingkat challenge adalah 0,66521 dimana lebih kecil dari nilai rata-ratanya yaitu 3,5684, sehingga mengindikasikan bahwa hasil yang cukup baik. Hal tersebut dikarenakan standar deviasi adalah pencerminan penyimpangan yang sangat tinggi, sehingga penyebaran data menunjukkan hasil yang normal dan tidak menyebabkan bias.

Variabel tingkat benefit $\left(\mathrm{X}_{4}\right)$ memiliki nilai rata-rata sebesar 3,1027 dengan nilai minimum 1,00 dan nilai maksimum 4,57. Hal ini menunjukkan bahwa ratarata responden menganggap tingkat benefit dalam konvergensi IFRS cenderung rendah (stabil). Hal tersebut juga dapat dilihat dari nilai rata-rata lebih mendekati nilai maksimal, yang artinya sebagian besar responden cenderung menjawab ragu-ragu pada ke-enam item pernyataan dalam variabel tingkat benefit. Nilai standar deviasi yang dimiliki oleh tingkat benefit adalah 0,69188 dimana lebih kecil dari nilai rata-ratanya yaitu 3,1027, sehingga mengindikasikan bahwa hasil yang cukup baik. Hal tersebut dikarenakan standar deviasi adalah pencerminan penyimpangan yang sangat tinggi, sehingga penyebaran data menunjukkan hasil yang normal dan tidak menyebabkan bias.

Variabel tingkat awareness $(Y)$ memiliki nilai rata-rata sebesar 0,7756 dengan nilai minimum 0,00 dan nilai maksimum 1,30. Hal ini menunjukkan mahasiswa akuntansi di Universitas Provinsi Bali aware terhadap konvergensi IFRS. Hal tersebut juga dapat dilihat dari nilai rata-rata lebih mendekati nilai maksimal, yang artinya sebagian besar responden cenderung aware atau peduli terhadap konvergensi IFRS pada ke-dua item pertanyaan. Nilai standar deviasi yang dimiliki oleh tingkat benefit adalah 0,51924 dimana lebih kecil dari nilai rata-ratanya yaitu 0,7756, sehingga mengindikasikan bahwa hasil yang cukup baik. Hal tersebut dikarenakan standar deviasi adalah pencerminan penyimpangan yang sangat tinggi, sehingga penyebaran data menunjukkan hasil yang normal dan tidak menyebabkan bias.

Teknik analisis yang digunakan dalam penelitian ini adalah analisis regresi linier berganda. Hasil analisis regresi linier berganda disajikan dalam Tabel 4.

Tabel 4. Hasil Uji Regresi Linier Berganda

\begin{tabular}{|c|c|c|c|c|c|}
\hline \multirow[t]{2}{*}{ Model } & \multicolumn{2}{|c|}{ Unstandardized Coefficients } & \multirow{2}{*}{$\begin{array}{c}\begin{array}{c}\text { Standardized } \\
\text { Coefficients }\end{array} \\
\text { Beta }\end{array}$} & \multirow[t]{2}{*}{$\mathrm{t}$} & \multirow[t]{2}{*}{ Sig. } \\
\hline & $B$ & Std. Error & & & \\
\hline (Constant) & .237 & .390 & & .609 & .543 \\
\hline $\mathrm{TI}$ & .062 & .015 & .249 & 4.012 & .000 \\
\hline TK & .100 & .030 & .230 & 3.377 & .001 \\
\hline $\mathrm{TC}$ & -.087 & .012 & -.394 & -7.066 & .000 \\
\hline TB & .044 & .016 & .177 & 2.745 & .006 \\
\hline F hitung & 30,658 & & & & \\
\hline
\end{tabular}


Lanjutan Tabel 3.

\begin{tabular}{lll}
\hline Signifikansi F & $:$ & 0,000 \\
$R$ Square & $:$ & 0,307 \\
Adjusted R Square & $:$ & 0,297
\end{tabular}

Sumber: Data Penelitian, 2018

Koefisien Determinasi pada model regresi moderasi dilihat dari nilai Adjusted R-Square sebesar 0,297. Hal ini berarti bahwa sebesar 0,297 atau 29,7\% variasi tingkat awareness mampu dijelaskan oleh variabel tingkat interest, knowledge, challenge, dan benefit. Sisanya sebesar 70,3\% dipengaruhi oleh variabel lain yang tidak masuk dalam model.

Uji F digunakan untuk melihat kelayakan model penelitian. Berdasarkan

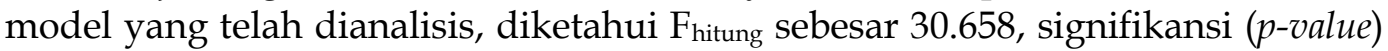
sebesar 0,000 . Berdasarkan nilai toleransi yang diberikan yaitu $a=5 \%$ dengan nilai signifikansi $0,000<$ a $(0,05)$, hal ini mengandung arti bahwa seluruh variabel mampu memprediksi atau menjelaskan fenomena tingkat awareness mahasiswa akuntansi di Universitas Provinsi Bali dan model regresi yang digunakan dianggap layak uji.

Tabel 4 menunjukkan hasil analisis pengaruh tingkat interest terhadap awareness mahasiswa akuntansi diperoleh koefisien regresi $\left(\beta_{1}\right)$ sebesar 0,062 dengan arah positif dan nilai signifikansi 0,000 lebih kecil dari a $(0,000<0,05)$, maka $\mathrm{H}_{1}$ diterima. Hal ini menyebabkan semakin tinggi tingkat interest mahasiswa akuntansi maka semakin tinggi pula tingkat awareness mahasiswa akuntansi mengenai konvergensi IFRS.

Jawaban responden menunjukkan bahwa tingkat interest mahasiswa akuntansi di Universitas Provinsi Bali cenderung tinggi karena keberhasilan mereka dalam mempelajari IFRS bergantung pada mahasiswa masing-masing. Hal tersebut tentunya akan meningkatkan awareness mahasiswa akuntansi pada konvergensi IFRS. Mahasiswa akan melakukan perilaku belajar yang baik seperti dapat dilihat dari kebiasaan mengikuti pelajaran, kebiasaan membaca buku, kunjungan ke perpustakaan dan kebiasaan menghadapi ujian. Oleh karena itu, dengan perilaku belajar atau minat belajar yang baik akan mengarah pada pemahaman terhadap pelajaran yang maksimal. Hasil penelitian ini sejalan dengan penelitian yang dilakukan oleh Ishak, 2010, Atmaja et al., 2017, dan Widaningrum et al., 2010 bahwa minat belajar mahasiswa berpengaruh positif terhadap pemahaman IFRS. Penelitian dari (Helen \& Raymond, 2013) juga menyatakan bahwa hampir semua mahasiswa di Hongkong tertarik mempelajari IFRS. Teori Taksonomi Bloom dalam ranah kedua mengenai ranah afektif, terdapat tingkatan yang salah satunya tingat penerimaan yang berhubungan juga dengan sikap. Hal ini dapat ditunjukkan dengan sikap mahasiswa ketika mendengarkan penjelasan pendidik dimana mereka mau menerima nilai-nilai yang diajarkan pada mereka dan mereka memiliki kemauan untuk menggabungkan diri dengan nilai tersebut. Tentunya dalam hubungannya mempelajari IFRS jika memiliki minat terhadap nilai yang diajarkan tersebut maka seseorang tersebut akan meningkatkan awareness mahasiswa terhadap IFRS

Pada Tabel 4, hasil analisis pengaruh tingkat knowledge terhadap awareness mahasiswa akuntansi diperoleh koefisien regresi $\left(\beta_{2}\right)$ sebesar 0,100 dengan arah posotif dan nilai signifikansi 0,001 lebih kecil dari a $(0,001<0,05)$ maka $\mathrm{H}_{2}$ 
diterima. Hal ini menyebabkan semakin tinggi tingkat knowledge yang dimiliki mahasiswa akuntansi maka akan semakin tinggi pula awareness mahasiswa terhadap konvergensi IFRS.

Jawaban responden mahasiswa terkait tingkat knowledge cenderung tinggi karena responden paling banyak memberikan jawaban pada pernyataan bahwa mahasiswa berusaha mengimplementasikan pembelajaran IFRS terutama dalam pembuatan laporan keuangan (pernyataan X2.3). Hal ini tentunya akan membuat mahasiswa akuntansi di Universitas Provinsi Bali akan semakin aware atau peduli terhadap konvergensi IFRS karena apabila mahasiswa khusunya mahasiswa akuntansi sering mengimplementasikan pembelajaran IFRS maka pengetahuan yang didapat akan bertambah serta konsep pembuatan laporan keuangan berbasis IFRS akan semakin kuat. Pengetahuan mengenai IFRS didapat saat mempelajari Akuntansi Keuangan I, Akuntansi Keuangan II, Akuntansi Keuangan Lanjutan, Teori Pasar Modal, dan Teori Akuntansi. Hal ini sejalan dengan penelitian sebelumnya dari (Zeghal \& Mhedhbi, 2006) menyatakan bahwa tingkat edukasi berpengaruh signifikan positif terhadap proses adopsi IFRS. Penelitian dari (Patro \& Gupta, 2012) juga menyatakan bahwa kurangnya pengetahuan IFRS mahasiswa akuntansi yang nantinya akan memainkan peran penting dalam menyukseskan konvergensi IFRS. Teori Taksonomi Bloom juga menyatakan bahwa dalam ranah pertama terdapat tingkatan pengetahuan. Ranah pertama dari teori Bloom sangat berhubungan dengan awareness mahasiswa, dimana apabila mahasiswa memiliki pengetahuan yang tinggi mengenai IFRS maka tingkatan yang lebih tinggi akan tercapai dan secara otomatis akan aware terhadap pembelajaran IFRS.

Pada Tabel 4, hasil analisis pengaruh tingkat challenge terhadap awareness mahasiswa akuntansi diperoleh koefisien regresi $\left(\beta_{3}\right)$ sebesar $-0,087$ dengan arah negatif dan nilai signifikansi 0,000 lebih kecil dari a $(0,000<0,05)$ maka $\mathrm{H}_{3}$ diterima. Hal ini menyebabkan semakin tinggi tingkat challenge yang dimiliki mahasiswa akuntansi maka akan semakin rendah tingkat awareness mahasiswa terhadap konvergensi IFRS.

Jawaban responden mahasiswa terkait tingkat challenge tinggi yang dibuktikan pada pernyataan materi mengenai IFRS perlu ditingkatkan lagi bagi mahasiswa akuntansi. Hal ini tentunya harus menjadi fokus utama bagi DSAKIAI serta tenaga pengajar di Universitas agar mahasiswa bisa lebih bisa mendalami dan mengimplementasikan penyusunan laporan keuangan sesuai dengan standar IFRS dan tentunya bisa menghadapi tantangan-tantangan yang dihadapi. Berdasarkan hal tersebut, IASB harus fokus dalam implementasi IFRS serta meminimalisir tantangan-tantangan terkait konvergensi IFRS. Negara yang ingin mengadopsi IFRS apabila dalam rencana tersebut banyak terdapat tantangan yang dihadapi maka negara tersebut lebih memilih untuk tetap mempertahankan Standar domestik yang diterapkan pada negara masingmasing dan implementasinya banyak mahasiswa masih mempelajari standar yang belum dikonvergensi ke IFRS karena negara masih enggan untuk mensosialisasikan mengenai konvergensi IFRS. . Hasil penelitian ini sejalan dengan penelitian yang dilakukan oleh Phan et al., 2018 bahwa tantangan yang dirasakan dalam kemauan dalam mengadopsi adalah berpengaruh negatif. (Sharma et al., 2017) juga merekomendasikan agar IASB sekarang harus fokus 
pada implementasi IFRS, selain memperbarui / membuat IFRS dengan pandangan untuk meminimalkan kesulitan yang dihadapi oleh negara yang akan implementasi. Teori Taksonomi Bloom dalam ranah ketiga yaitu menjelaskan mengenai ranah psikomotorik. Jika dikaitkan dengan awareness pada konvergensi IFRS apabila seseorang dalam mempelajari standar akuntansi tidak bisa hanya memahami dan menghapalkan standar tersebut melainkan kita harus melatih bagian pskomotrik kita agar kita terbiasa menggunakan standar akuntansi yang berlaku global tersebut sehingga apabila terdapat tantangantantangan dapat diatasi dengan mudah.

Pada Tabel 4, hasil analisis pengaruh tingkat benefit terhadap awareness mahasiswa akuntansi diperoleh koefisien regresi $\left(\beta_{4}\right)$ sebesar 0,044 dengan arah positif dan nilai signifikansi 0,006 lebih kecil dari a $(0,006<0,05)$ maka $\mathrm{H}_{4}$ diterima. Hal ini menyebabkan semakin tinggi tingkat benefit yang dimiliki mahasiswa akuntansi maka akan semakin tinggi pula awareness mahasiswa terhadap konvergensi IFRS.

Jawaban responden mahasiswa terkait tingkat benefit cenderung tinggi karena responden paling banyak memberikan jawaban pada pernyataan bahwa Konvergensi IFRS dapat meningkatkan penyampaian informasi keuangan dari berbagai negara akan lebih reliable, relevan, transparan, dan dapat dipahami. Banyak sekali manfaat yang akan didapat oleh mahasiswa setelah mempelajari IFRS. Hal ini tentunya akan membuat mahasiswa lebih banyak mempelajari IFRS karena saat ini IFRS sudah digunakan oleh berbagai negara untuk pelaporan keuangannya. Secara tidak langsung, mahasiswa harus bisa menyesuaikan kemampuannya untuk bersaing dalam standar global. Sehubungan dengan hal tersebut, peran institusi menghadapi perubahan tersebut harus membawa dampak yang besar bagi pengemban ilmunya agar dapat memberikan benefit yang besar. Sejalan dengan penelitian yang dilakukan oleh Phan et al., 2018, Brochet et al., 2011, dan Soderstrom \& Sun, 2008 bahwa manfaat yang dirasakan seperti, komparabilitas dan reliabilitas yang terkait dengan IFRS berpengaruh positif terhadap kemauan untuk mengadopsi IFRS. Teori Taksonomi Bloom menyatakan apabila seseorang sudah menguasai ranah-ranah yang dijabarkan oleh Bloom maka seseorang tersebut akan menguasai sesuatu yang dipelajarinya karena sangat berkaitan dengan proses belajar mengajar yang dilakukan oleh mahasiswa. Untuk kedepannya, mahasiswa tersebut akan siap menjadi calon sumber daya yang berguna dan tentunya berkualitas.

\section{SIMPULAN}

Berdasarkan hasil penelitian yang diperoleh melalui pengujian statistik serta pembahasan seperti yang telah diuraikan, maka dapat disimpulkan bahwa: Tingkat interest mahasiswa akuntansi berpengaruh signifikan positif terhadap awareness konvergensi IFRS di Universitas Provinsi Bali. Hal ini berarti semakin tinggi tingkat interest mahasiswa akuntansi maka semakin tinggi pula tingkat awareness-nya terhadap konvergensi IFRS. Tingkat knowledge mahasiswa akuntansi berpengaruh signifikan positif terhadap awareness konvergensi IFRS di Universitas Provinsi Bali. Hal ini berarti semakin tinggi tingkat knowledge yang dimiliki mahasiswa akuntansi maka semakin tinggi pula tingkat awareness-nya terhadap konvergensi IFRS. Tingkat challenge mahasiswa akuntansi berpengaruh 
signifikan negatif terhadap awareness konvergensi IFRS di Universitas Provinsi Bali. Hal ini berarti semakin tinggi tingkat challenge yang dihadapi mahasiswa akuntansi maka semakin rendah tingkat awareness-nya terhadap konvergensi IFRS. Tingkat benefit mahasiswa akuntansi berpengaruh signifikan positif terhadap awareness konvergensi IFRS di Universitas Provinsi Bali. Hal ini berarti semakin tinggi tingkat benefit yang dirasakan mahasiswa akuntansi maka semakin tinggi pula tingkat awareness-nya terhadap konvergensi IFRS.

Berdasarkan hasil penelitian dan simpulan di atas, maka saran yang dapat diberikan adalah disarankan kepada DSAK-IAI serta tenaga pengajar akuntan lainnya untuk dapat menyelaraskan pemahaman mengenai standar IFRS. Disarankan kepada tenaga pengajar akuntan agar lebih menekankan kepada konsep mengenai pembelajaran IFRS serta sering melatih hardskill dari mahasiswa akuntansi agar mahasiswa memiliki kompetensi konsep dengan praktek yang seimbang. Disarankan kepada tenaga pengajar akuntan di Universitas Provinsi Bali untuk memberikan materi mengenai IFRS di kelas dengan intens agar mahasiswa akuntansi dapat mendalami tentang standar IFRS yang berlaku di Indonesia. Disarankan kepada DSAK-IAI apabila IASB mengeluarkan dan mengembangkan standar akuntansi maka sebaiknya DSAKIAI mendiskusikan terlebih dahulu kepada tenaga akuntan serta pengajar akuntan. Disarankan untuk penelitian selanjutnya dapat memperluas objek penelitian yaitu dengan dosen pengajar serta dapat menguji dengan variabel lainnya karena berdasarkan nilai adjusted R-Square tersisa sebesar 70,3\% yang masih dipengaruhi oleh variabel lain yang tidak dimasukkan dalam model seperti tingkat pedagogy, introduce, serta legitimacy, serta disarankan untuk menambah pertanyaan essay dalam kuisioner, dan menambah metode wawancara dalam pengumpulan data.

\section{REFRENSI}

Amiaty, R. E. (2015). Persiapan Bank Indonesia Dalam Menghadapi Masyarakat Ekonomi ASEAN 2015.

Atmaja, R., Ramantha, I. W., \& Suartana, I. W. (2017). Pengaruh Minat Belajar pada Pemahaman Akuntansi dengan Kecerdasan Emosional dan Spiritual sebagai Pemoderasi, 5, 2021-2046.

Barth, M. E., \& et al. (2008). International accounting standards and accounting quality. Journal of Accounting Research, 46(3), 467-498. https:// doi.org/10.1111/j.1475-679X.2008.00287.x

Brochet, F., Riedl, E. J., Brochet, F., Jagolinzer, A., \& Riedl, E. J. (2011). Mandatory IFRS Adoption and Financial Statement Comparability Mandatory IFRS Adoption and Financial Statement Comparability. Harvard Business School.

Christiani, Y. N. (2015). Pemahaman Mahasiswa Akuntansi Terhadap Internasional Financial Reporting Standar (IFRS).

Farahmita, A. (2012). Analisis faktor-faktor yang mempengaruhi kemungkinan adopsi ifrs di negara berkembang, 15.

Flynn, T. (2008). US warming to IFRS as it moves on from GAAP, http:/ / www.ft.com/cms/s/0/e944709e-7a19-11dd-bb93000077b07658.html?nclick_check=1

Fong, A. (2016). International Financial Reporting Standards (IFRS). Jurnal 
Akuntansi Manajerial, 1(1), 12-21.

Gayatri, Widanaputra, \& Suprasto, B. (2016). Pemahaman Mahasiswa Jurusan Akuntansi Atas Penerapan International Financial Reporting Standard Dalam Menghadapi Masyarakat Ekonomi Asean. Jurnal Ilmiah Akuntansi Dan Bisnis, 11(1), 11-16.

Helen, W., \& Raymond, W. (2013). An Empirical Study - Adoption of International Financial Reporting Standards (IFRS) in Hong Kong Education. Journal of Management Research, 5(4), 98. https://doi.org/10.5296/jmr.v5i4.4256

Heykal, M., Siagian, P., \& Iswandi. (2014). Impact Analysis of Indonesian Financial Accounting Standard based on the IFRS Implementation for Financial Instruments in the Indonesian Commercial Bank. Procedia - Social and Behavioral Sciences, 109, 1247-1250. https://doi.org/10.1016/j.sbspro.2013.12.620

International Accounting Education Standards Board (IAESB). (2010). International Education Standard IES 3 Professional Skills and General Education. New York, NY: IFAC

Ishak, P. (2010). Pengaruh Kecerdasan Emosional, Kecerdasan Spiritual Dan Minat Belajar Terhadap Pemahaman Akuntansi (Studi Pada Mahasiswa Akuntansi Universitas Brawijaya Malang Angkatan 2010), (2003).

Mala, R., \& Chand, P. (2012). Effect of the Global Financial Crisis on Accounting Convergence. CFA Digest, 42(2), 81. https://doi.org/10.2469/ dig.v42.n2.57

Milne, Markus J., Phillip J.MC. (2001). Problem-based learning: a pedagogy for using case material in accounting education. Accounting Education Journal, 10(1).

Moqbel, \& Bakay. (2010). Are US academics and professionals ready for IFRS? an explanation using technology acceptance model and theory of planned behavior. Journal of International Business Research, 12(2), 47-61.

Nilsen K. (2008). On the Verge of an Academic Revolution: How IFRS is affecting Accounting Education. Journal of Accountancy, Dec.

Nuraini, M. (2007). Pengaruh Kecerdasan Emosional Dan Minat Belajar Mahasiswa Akuntansi Terhadap Tingkat Pemahaman Akuntansi. Maya Nuraini. Jurnal Beta, 5, 4-9.

Nurunnabi, M. (2014). "Does accounting regulation matter?": An experience of international financial reporting standards implementation in an emerging country. Research in Accounting Regulation, 26(2), 230-238. https://doi.org/10.1016/j.racreg.2014.09.012

Patro, A., \& Gupta, V. K. (2012). Adoption of International Financial Reporting Standards (IFRS) in Accounting Curriculum in India-An Empirical Study. Procedia Economics and Finance, 2(January 2005), 227-236. https://doi.org/10.1016/S2212-5671(12)00083-4

Phan, D., Joshi, M., \& Mascitelli, B. (2018). What influences the willingness of Vietnamese accountants to adopt International Financial Reporting Standards (IFRS) by 2025? Asian Review of Accounting, 26(2), 225-247. https://doi.org/10.1108/ARA-03-2017-0052

Poudel, G., \& Hellmann, A. P. (2014). The adoption of International Financial 
Reporting Standards in a non-colonized developing country: The case of Nepal. Advances in Accounting, Incorporating Advances in International Accounting, $\quad 3-5 . \quad$ Retrieved from http:// search.ebscohost.com/login.aspx?direct=true\&db=edselp\&AN=S088 2611014000054\&site=eds-live Saito, M., Hiramatsu, K., \& Mayangsari, S. (2012). Accounting Education for the Implementation of IFRS in Indonesia. International Review of Business, 12(22402053), 1-21.

Ramlan Effendi. (2015). Konsep Revisi Taksonomi Bloom Dan Implementasinya Pada Pelajaran Matematika SMP Ramlan Effendi. Jurnal Ilmiah Pendidikan Matematika, 2, 72-78.

Sharma, S., Joshi, M., \& Kansal, M., 2017. IFRS adoption challenges in developing economies: an Indian perspective. Managerial Auditing Journal, 32(4/5), 406426.

Soderstrom, N. S., \& Sun, K. J. (2008). IFRS Adoption and Accounting Quality : A Review IFRS Adoption and Accounting Quality : A Review, (June 2013), 3741.

Susanti. (2018). Tingkat Pemahaman Dan Persepsi Mahasiswa Terhadap Penerapan Ifrs ( Studi Empiris Pada Mahasiswa Universitas Sains Al- Qur ' an Jawa Tengah Di Wonosobo ). Ppkm I, 49-60.

Suyatmini dan Sheilla, A. (2014). Kajian tentang konvergensi international financial reportingstandard (ifrs) di indonesia. Jurnal Pendidikan Ilmu Sosial, 24, 79-86.

Widaningrum, N. H., Praptapa, A., \& Ulfah, P. (2010). Pengaruh Ketersediaan Sarana Pendidikan Dan Kecerdasan Emosional Terhadap Tingkat Pemahaman IFRS Dengan Minat Sebagai Variabel Moderating Di Fakultas Ekonomi UNSOED. Simponsium Nasional Akuntansi XIII, (8), 1-23.

Zeghal, D., \& Mhedhbi, K. (2006). An analysis of the factors affecting the adoption of international accounting standards by developing countries. The International Journal of Accounting, 41, 373-386. https://doi.org/10.1016/j.intacc.2006.09.009 